\title{
Effect of inhibitors in clinical specimens on Taq and Tth DNA polymerase-based PCR amplification of influenza $A$ virus
}

\author{
S. K. PODDAR, M. H. SAWYER and J. D. CONNOR \\ Department of Pediatrics, Division of Infectious Diseases, University of California at San Diego, La Jolla, CA \\ 92093-0808, USA
}

\begin{abstract}
Fifteen randomly selected nasopharyngeal (NP) swab specimens (culture-negative for influenza $A$ virus) were spiked with influenza $A$ virus and the nucleic acids were extracted and subjected to PCR amplification with Thermus aquaticus (Taq) and $T$. thermophilus (Tth) DNA polymerases. Products of the expected size, and giving equivalent band intensities, were obtained from four specimens with both polymerases. Fox six specimens, less products were obtained with Taq DNA polymerase than with $T$ th DNA polymerase. Products were detected from five NPs only by PCR with Tth DNA polymerase. The transport medium and the calcium alginate swab fibre of the specimens were shown not to be the source of the inhibitors. The incorporation of ${ }^{32} \mathrm{P}$-dCTP into cDNA, and the yield of PCR products of CDNA made from control RNA template (purified from $\mathrm{H}_{2} \mathrm{O}$ spiked virus suspension) were decreased in the presence of inhibitory extracts, showing that both the reverse transcription (RT) and PCR steps in amplification with Taq DNA polymerase were sensitive to the inhibitors. In contrast, Tth DNA polymerase was more resistant to the inhibitors and viral nucleic acid from all the specimens examined could be amplified and detected in a single step by RT-PCR with Tth DNA polymerase.
\end{abstract}

\section{Introduction}

Influenza A virus, a member of the Orthomyxoviridae family [1], is a major causative agent of a broadspectrum respiratory illness in man [2]. A diagnosis of the viral infection is essential to provide proper therapeutic steps that can reduce the progression as well as severity of illness and a rapid diagnosis can be crucially important for better management of patients, particularly those at high risk. In addition, a rapid diagnosis can help eliminate the chances of inappropriate therapy and facilitates surveillance and control of transmission of the disease. The standard laboratory method for diagnosis of influenza A infection is based on isolation of the virus in tissue culture [3]. However, the tissue culture method is tedious and very time consuming and it is virtually impossible to make an early therapeutic intervention based on detection of the virus by this method. The enzyme-linked immunosorbent assay (ELISA) and immunofluorescence assay

Received 31 Oct. 1997; revised version accepted 16 March 1998.

Corresponding author: Dr S. K. Poddar.
(IFA) have been described for rapid detection of the infection [4]. The polymerase chain reaction (PCR) provides another approach that allows rapid detection of influenza virus and other viral pathogens [5-7] and has been shown to be more sensitive than the standard virological method [5].

Amplification of a target RNA, such as the genome of influenza A virus, involves reverse transcription of RNA to cDNA by the enzyme reverse transcriptase (RT) and subsequent PCR amplification of cDNA by a thermostable DNA polymerase. In previous PCR studies with influenza A virus, Taq DNA polymerase (from Thermus aquaticus) has been used for cDNA amplification $[5,6]$. However, this Taq DNA polymerase-based amplification method has been reported to produce false negative results for some clinical specimens $[8,9]$ because of the presence of inhibitors.

An alternative to Taq DNA polymerase-based PCR could be that based on the Tth DNA polymerase, a relatively sturdy enzyme [10] from the thermophilic bacterium $T$. thermophilus. The Tth enzyme has both RT and DNA polymerase activity. Therefore, a convenient PCR amplification of RNA is possible in 
a single reaction mixture with Tth DNA polymerase. An optimised single tube RT-PCR procedure for amplification and detection of influenza A virus with Tth enzyme has been reported [11]. The present study compared Taq DNA polymerase-based PCR following reverse transcription, with the $T$ th enzyme-based RTPCR amplification for influenza $A$ virus detection in nasopharyngeal (NP) specimens.

\section{Materials and methods}

\section{Virus strain and media}

Influenza virus A (H1N1) was obtained from the Department of Public Health, San Diego, CA, USA. The titre of the concentrated stock was $4 \times 10^{4}$ TCID50 $/ \mathrm{ml}$. The virus strain was cultured, typed and propagated at the virology laboratory of the Department of Public Health, San Diego. The virus was diluted in three media: (1) diethyl pyrocarbonate (DEPC)-treated distilled $\mathrm{H}_{2} \mathrm{O}$ (control medium); (2) veal infusion broth (VIB) (transport medium); and (3) DEPC-treated $\mathrm{H}_{2} \mathrm{O}$ incubated overnight with a fresh calcium alginate swab. Ten-fold dilutions to 1 in $10^{6}$ of the influenza A virus $(\mathrm{H} 1 \mathrm{N1})$ stock were prepared in each medium.

\section{Clinical specimens}

Nasopharyngeal (NP) swab specimens were obtained from the clinical virology laboratory, University of California at San Diego (UCSD) Medical Center. The NP specimens used in this study were all negative for influenza A virus by culture, and also both Taq and Tth DNA polymerase-based PCR. The NP specimens, stored at $-70^{\circ} \mathrm{C}$, were thawed and a dilution series of influenza $A$ virus (H1N1) was prepared as in the control medium, in each of the specimens.

\section{Nucleic acid target preparation}

The RNA was isolated from $200 \mu$ l of influenza viral suspension in medium or in NP specimens with a QIamp kit (Qiagen Inc, Chatsworth, CA, USA) and following the protocol provided by the manufacturer. The RNA was eluted in $100 \mu \mathrm{l}$ of $10 \mathrm{~mm}$ Tris- $\mathrm{HCl}(\mathrm{pH}$ 9.0). The extracted RNA solution was stored at $-20^{\circ} \mathrm{C}$ and used for PCR amplification within 1 week.

\section{Primers}

The sense primer (5'CCGAGATCGCAGCAGAGACTTGAAGAT3'), and the antisense primer (5'GGCAAGTGCACCAGCAGAATAACT3'), derived from the conserved regions in the coding sequence of the matrix protein gene of influenza A virus genome, were identical to those used in a previous study [5], and were purchased from Life Technologies, Gaithesburg, MD, USA.
cDNA synthesis and PCR with Taq polymerase

cDNA synthesis was performed in a reaction mixture containing $10 \mu \mathrm{l}$ of target RNA, $10 \mathrm{mM}$ Tris- $\mathrm{HCl}(\mathrm{pH}$ $8.3), 50 \mathrm{mM} \mathrm{KCl}, 1.25 \mathrm{mM} \mathrm{MgCl} 2,0.05 \mathrm{mM}$ of each dNTP (Promega), $20 \mathrm{U}$ of RNasin (Promega), $100 \mathrm{U}$ of Moloney murine leukaemia virus reverse transcriptase (MMLV-RT) (Promega) and $250 \mu \mathrm{g}$ of random primers (Promega) in a total volume of $20 \mu \mathrm{l}$. The cDNA synthesis conditions consisted of one cycle of $10 \mathrm{~min}$ at $25^{\circ} \mathrm{C}, 20 \mathrm{~min}$ at $42^{\circ} \mathrm{C}$ followed by $5 \mathrm{~min}$ at $95^{\circ} \mathrm{C}$ (for inactivating the remnants of reverse transcriptase) in a thermocycler 2400 (Perkin Elmer Cetus, Norwalk, CT, USA). The reaction was then stored at $4^{\circ} \mathrm{C}$ until used for PCR. The 20- $\mu 1 \mathrm{cDNA}$ reaction mixtures were then added to $30 \mu 1$ of PCR reaction mixture such that final concentrations of the reaction components were as follows: $1 \times$ Perkin Elmer PCR buffer II $(10 \mathrm{mM}$ Tris$\mathrm{HCl}$, pH $8.9 ; 50 \mathrm{mM} \mathrm{KCl}$; gelatin $0.01 \%$ ), $2.5 \mathrm{mM}$ $\mathrm{MgCl}_{2}, 200 \mu \mathrm{M}$ each of dATP, dCTP, dGTP and dUTP, $0.5 \mu \mathrm{M}$ each of the sense and antisense primers, $0.5 \mathrm{U}$ of Uracil N-glycosylase (UNG) and $1.25 \mathrm{U}$ of Taq DNA polymerase (Perkin Elmer). The amplification reactions were performed in the thermocycler 2400 with a precycle of $25^{\circ} \mathrm{C}$ for $10 \mathrm{~min}$, for UNG digestion of any carried over DNA contaminants, followed by incubation at $95^{\circ} \mathrm{C}$ for $10 \mathrm{~min}$ to inactivate $\mathrm{UNG}$. Amplification conditions consisted of 40 cycles of $94^{\circ} \mathrm{C}$ for $10 \mathrm{~s}, 60^{\circ} \mathrm{C}$ for $15 \mathrm{~s}$ and $72^{\circ} \mathrm{C}$ for $30 \mathrm{~s}$.

\section{RT-PCR by Tth polymerase}

Target RNA $(10 \mu 1)$ was amplified in a $50-\mu 1$ reaction mixture containing $300 \mu \mathrm{M}$ of each dNTP, $500 \mu \mathrm{M}$ dUTP, $0.5 \mu \mathrm{M}$ each of the sense and antisense primers, $0.5 \mathrm{U}$ of UNG, $2.5 \mathrm{U}$ of Tth DNA polymerase (Perkin Elmer) and $3.0 \mathrm{mM} \mathrm{Mn}(\mathrm{OAc})_{2}$, in $1 \times \mathrm{PCR}$ buffer for Tth enzyme (Perkin Elmer). The precycle conditions consisted of incubation for $10 \mathrm{~min}$ at $25^{\circ} \mathrm{C}$ for digestion of carried over DNA by UNG, 2 min at $95^{\circ} \mathrm{C}$ for UNG inactivation, $30 \mathrm{~min}$ at $60^{\circ} \mathrm{C}$ for reverse transcription and $3 \mathrm{~min}$ at $94^{\circ} \mathrm{C}$ for removal of secondary structure of cDNA. The amplification conditions were as described above.

\section{Positive and negative PCR controls}

Control RNA $(10 \mu 1$ out of $100 \mu 1)$ isolated from $200 \mu 1$ of $40-400 \mathrm{TCID}^{50} / \mathrm{ml}$ of influenza $\mathrm{A}$ virus suspension in DEPC-treated water was used as the positive control for PCR. DEPC-treated $\mathrm{H}_{2} \mathrm{O}(10 \mu \mathrm{l})$ and a non-specific target RNA (PAW 109 RNA, Perkin Elmer Cetus) were used as the negative controls for the PCR.

\section{Electrophoresis in agarose gels}

Final reaction products $(10 \mu \mathrm{l})$ were analysed by electrophoresis in TBE buffer $(89 \mathrm{~mm}$ Tris-borate, $2 \mathrm{mM}$ EDTA, pH. 8.3) in an agarose (2\%) gel containing ethidium bromide $1 \mu \mathrm{g} / \mathrm{ml}$. After electro- 
phoresis the DNA bands were visualised with a UV transilluminator.

\section{Reverse transcription (RT) assay}

A mixture $(10 \mu \mathrm{l})$ containing $20 \mathrm{mM}$ Tris- $\mathrm{HCl}(\mathrm{pH} 8.3)$, $100 \mathrm{mM} \mathrm{KCl}, 2.5 \mathrm{mM} \mathrm{MgCl}_{2}, 40 \mathrm{U}$ RNasin (Promega), 10 pmol antisense primer, $5 \mu \mathrm{l}$ of control RNA or $5 \mu \mathrm{l}$ of control RNA plus $1 \mu \mathrm{l}$ of RNA extracted from NP specimen no. 5 spiked with a 1 in $10^{3}$ dilution of stock virus and diluted five-fold to 1 in 625 , was incubated at $70^{\circ} \mathrm{C}$ for $10 \mathrm{~min}$. Reactions were initiated by the addition of a $10-\mu 1$ mixture containing $100 \mu \mathrm{M}$ each of dATP, dGTP, dTTP and $\alpha-{ }^{32} \mathrm{P}$ dCTP $(3.0 \mathrm{Ci} / \mathrm{mmol})$ and $100 \mathrm{U}$ of MMLV-RT. The final reaction mixture was incubated at $42^{\circ} \mathrm{C}$ for $30 \mathrm{~min}$ and the reaction was terminated by incubating at $95^{\circ} \mathrm{C}$ for $10 \mathrm{~min}$. Ten $\mu \mathrm{l}$ of the reaction mixture were then added to $500 \mu \mathrm{l}$ of trichloroacetic acid (TCA) $10 \%$ and incubated in ice for $30 \mathrm{~min}$. Unincorporated $\alpha-{ }^{32} \mathrm{P}$ dCTP was removed by passing the mixture through a membrane filter of pore size $0.45 \mu \mathrm{m}$ (Millipore) and the incorporation of ${ }^{32}$ P-labelled dCTP in the synthesised cDNA was determined from TCA precipitable counts detected by Cerenkov radiation [12].

\section{Results}

Amplification of target nucleic acids from nasopharyngeal swab specimens spiked with virus

Amplification of nucleic acid extracted from each of 15 NP specimens spiked with influenza A virus was attempted with Taq DNA polymerase-based and Tth enzyme-based PCR. Products of the expected size (311 bp) and giving equivalent band intensities were obtained for four specimens with both polymerases. Viral nucleic acids from six specimens were detected with at least 10 -fold more sensitivity when amplified by Tth enzyme than by Taq DNA polymerase (e.g., nos. 1 and 6 in Fig. 1). For five specimens, no products were detected with Taq polymerase (e.g., specimens 25, Fig. 1). Positive control RNA was amplified equally by Taq and Tth DNA polymerases (not shown). The data indicated that, for some NPs, PCR by Taq polymerase was partially or totally inhibited as compared with that by the Tth enzyme-based method.

Effect of mixing inhibitory or partially inhibitory extracts with control RNA in PCR

A sample from each of the five-fold dilutions of an inhibitory sample extract was mixed with the control RNA (isolated from $\mathrm{H}_{2} \mathrm{O}$ spiked with virus suspension), cDNA was made and was then amplified by Taq polymerase. The addition of $1 \mu 1$ of extract from spiked specimen nos. 2 and 5 resulted in no products from control RNA. The amplification was restored when the extract from specimen no. 2 was diluted at least 1 in 25 and that from specimen 5 was diluted at least 1 in 5 . To eliminate inhibition from other NP specimens, dilutions between 1 in 5 and 1 in 125 were required (not shown).

\section{Effect of VIB and calcium alginate swab on PCR} with Taq polymerase

The expected 311-bp amplified DNA fragment was detected in virus diluted to 1 in $10^{3}$ in water, in VIB and in $\mathrm{H}_{2} \mathrm{O}$ incubated with calcium alginate swabs. Identical results were obtained when different batches of VIB and calcium alginate swabs were examined.

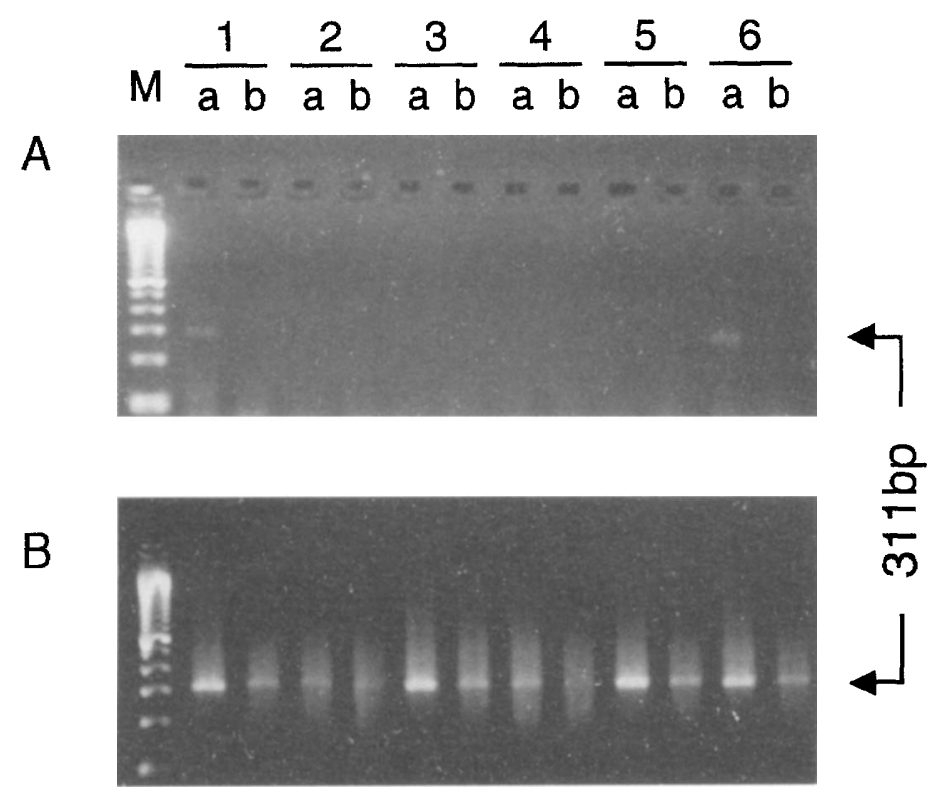

Fig. 1. Example of influenza A virus PCR inhibition by NP specimens. A, PCR with Taq DNA polymerase; B, PCR with Tth DNA polymerase. The dilutions of virus used for spiking each NP specimen were: $\mathbf{a}, 10^{2} ; \mathbf{b}, 10^{3}$. M, molecular size marker (100 bp, DNA ladder, Life Technologies). 
Effect of inhibitors from NP specimens in RT and $P C R$

To characterise the inhibitor in NP specimens with respect to its effect in the reverse transcription step, control RNA was reverse transcribed in the presence of $\alpha-{ }^{32} \mathrm{P}-\mathrm{dCTP}$, with and without additional nucleic acid (RNA) from a representative inhibitory NP specimen (no. 5) spiked with the virus. The incorporation of ${ }^{32} \mathrm{P}-$ labelled dCTP in the cDNA synthesised by reverse transcriptase decreased with the increased concentration of the added nucleic acids extract (Fig. 2). To examine the effect of inhibitors on the PCR step, cDNA was synthesised from control template RNA and different volumes of inhibitory extract from virusspiked NP specimen no. 5 were added before amplification with Taq DNA polymerase. The yield of amplified product decreased with the increasing addition of inhibitory extract. The addition of $4 \mu 1$ of nucleic acid extract completely inhibited PCR amplification by $T a q$ DNA polymerase. Qualitatively similar results were obtained for both RT and PCR steps with other inhibitory or partially inhibitory extracts (not shown). These results indicated that both the reverse transcription and PCR steps were adversely affected by the inhibitors in NP specimens.

\section{Discussion}

In this laboratory it had been observed that, for some influenza A virus culture-positive NP specimens, cDNA synthesis followed by PCR with Taq DNA polymerase gave false negative results, whereas amplification in a single tube [11] with Tth DNA polymerase gave positive results, as expected. In the present study, PCR amplification of standardised amounts of influenza A virus in NPs by Taq DNA polymerase and Tth DNA

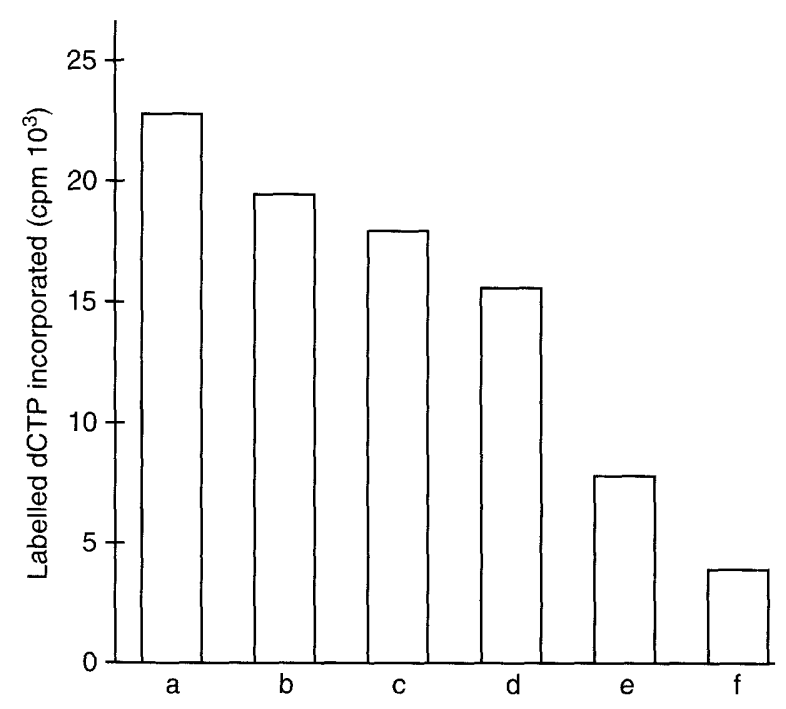

Fig. 2. Incorporation of $\alpha-{ }^{32} \mathrm{P}-\mathrm{dCTP}$ in the cDNA synthesised by reverse transcriptase from: a, control RNA alone or; b, control RNA plus $1 \mu \mathrm{l}$ of inhibitory extract from spiked NP specimen no. 5 diluted 1 in 625; c, 1 in $125 ; \mathbf{d}, 1$ in $25 ; \mathbf{e}, 1$ in $5 ; \mathbf{f}$, undiluted. polymerase were compared. Amplification of 10 -fold dilutions of virus in NP specimens showed that Tth enzyme detected 10-fold fewer copies than Taq polymerase for several of the NP specimens studied. When control RNA was mixed with inhibitory extracts from virus-spiked NP specimens and subjected to PCR with Taq polymerase, the extent of inhibition was shown to vary between specimens. The possibility that differences in the amount of inhibitors found in different NPs were due to differences in patients' medical conditions or stages of infection needs to be investigated further.

The results of the present study showed that the calcium alginate swabs and VIB transport medium did not inhibit PCR. Similarly, He et al. [13] successfully used calcium alginate or cotton NP swabs in PCRbased assays. In contrast, Wadowski et al. [14] found that calcium alginate and the aluminium shaft component of the swab in NP specimens were inhibitory for PCR. These differences in results may have been caused by differences in target nucleic acid preparation methods.

The fact that the activity of both reverse transcriptase and Taq DNA polymerase was inhibited by extracts from some NP specimens suggests that amplification by Taq DNA polymerase of target nucleic acids from other common respiratory infectious agents in an NP specimen may be inhibited. Unpublished experiments in this laboratory with Mycoplasma pneumoniae and respiratory syncytial virus in NP specimens showed inhibition of amplification by Taq DNA polymerase compared with that by Tth DNA polymerase, supporting further the notion that the PCR inhibition occurred by directly inhibiting the enzymic activity and that the inhibition was independent of the target or primer set used.

As amplification by Tth enzyme was detected in all samples, the lack of detectable products from samples nos. $2-5$ by Taq DNA polymerase-based PCR was not due to the absence of target RNA in the samples. In the PCR, reduced product DNA synthesis sometimes may occur because of the presence of nuclease activity in the nucleic acid sample. As samples that were inhibitory to amplification by Taq polymerase were amplified by Tth enzyme, the inhibition was not due to the presence of nucleases. The presence of unwanted metal ions in the nucleic acid sample could also inhibit PCR amplification. In a preliminary experiment, with nucleic acid isolated with Chelex100 (BioRad) to remove metal ions [15] from inhibitory samples, no improved amplification by $T a q$ DNA polymerase was detected (unpublished observation). This suggests that the inhibition was not caused by metal ions. Potent inhibitory proteins such as haemoglobin or carbonic anhydrase have been reported by other investigators to be simultaneously released with nucleic acid even when the standard phenol- 
chloroform-isoamylalcohol extraction method is used [16]. The QIamp procedure used in the present study allows rapid purification of nucleic acids from biological samples suitable for PCR-based assays [17]. However, it remains to be determined whether some specimens used in the present study contained large amounts of inhibitors that were not all removed and hence may have been co-purified to some extent with RNA by the QIamp procedure, causing inhibition.

Reports on the successful use of Tth DNA polymerase-based RT-PCR protocol incorporating UNG sterilisation in a single tube reaction are limited $[7,11]$. In the present study, amplification of target nucleic acid by $T$ th enzyme with such a single tube reaction protocol was found not to be perturbed by the inhibitors of Taq DNA polymerase present in the NP specimens. The single tube reaction protocol also reduces the sample handling time and the chances of exogenous contamination. In routine diagnostic protocols, these advantages make the presently used Tth enzyme-based PCR method preferable to cDNA synthesis followed by amplification with Taq DNA polymerase.

In summary, the present study showed that some NP specimens may contain inhibitors of both reverse transcriptase and Taq DNA polymerase, and the inhibitors may co-purify with nucleic acid. Dilution of nucleic acid extracts from such specimens (which would also decrease the sensitivity of the PCR), or the use of Tth DNA polymerase instead of Taq DNA polymerase, can minimise the possibility of false negative PCR amplification.

\section{References}

1. Murphy BR, Webster RG. Orthomyxoviruses. In: Fields BN, Knipe DM (eds) Virology vol 1, 2nd edn. New York, Raven Press. 1990: 1091-1152.

2. Harmon MW. Influenza viruses. In: Lennette $\mathrm{EH}$ (ed) Laboratory diagnosis of viral infections, 2nd edn. New York,
Marcel Dekker. 1992: 515-534.

3. Monto AS, Maassab HF, Bryan ER. Relative efficacy of embryonated eggs and cell culture for isolation of contemporary influenza viruses. J Clin Microbiol 1981; 13: 233-235.

4. Bucher DJ, Mikhail A, Popple S et al. Rapid detection of type A influenza viruses with monoclonal antibodies to the $M$ protein (M1) by enzyme-linked immunosorbent assay and timeresolved fluoroimmunoassay. $J$ Clin Microbiol 1991; 29: 2484-2488.

5. Cherian T, Bobo L, Steinhoff MC, Karron RA, Yolken RH Use of PCR-enzyme immunoassay for identification of influenza A virus matrix RNA in clinical samples negative for cultivable virus. J Clin Microbiol 1994; 32: 623-628.

6. Wright KE, Wilson GAR, Novosad D, Dimock C, Tan D, Weber JM. Typing and subtyping of influenza viruses in clinical samples by PCR. J Clin Microbiol 1995; 33: 1180-1184.

7. Mulder J, McKinney N, Christopherson C, Sninsky J, Greenfield $\mathrm{L}$, Kwok S. A rapid and simple PCR assay for quantitation of Human Immunodeficiency Virus type 1 RNA in plasma: application to acute retroviral infection. $J$ Clin Microbiol 1994; 32: 292-300.

8. Khan G, Kangro HO, Coates PJ, Heath RB. Inhibitory effects of urine on the polymerase chain reaction for cytomegalovirus DNA. J Clin Pathol 1991; 44: 360-365.

9. Zazzi M, Romano L, Brasini A, Valensin, PE. Low human immunodeficiency virus titer and polymerase chain reaction false-negatives. J Infect Dis 1992; 165: 779-780.

10. Katcher HL, Schwartz I. A distinctive property of Tth DNA polymerase: enzymatic amplification in the presence of phenol. Biotechniques 1994; 16: 84-92.

11. Poddar SK, Sawyer MH, Connor JD. Optimized PCR amplification of influenza A virus RNA using Tth DNA polymerase, incorporating uracil $\mathrm{N}$ glycosylase (UNG) in a single tube reaction. J Clin Lab Anal 1997; 11: 323-327.

12. Myers TW, Gelfand DH. Reverse transcription and DNA amplification by a Thermus thermophilus DNA polymerase. Biochemistry 1991; 30: 7661-7666.

13. He Q, Mertsola J, Soini H, Skurnik M, Ruuskanen O, Viljanen MK. Comparison of polymerase chain reaction with culture and enzyme immunoassay for diagnosis of pertussis. $J$ Clin Microbiol 1993; 31: 642-645.

14. Wadowsky RM, Laus S, Libert T, States SJ, Ehrlich GD. Inhibition of PCR-based assay for Bordetella pertussis by using calcium alginate fiber and aluminium shaft components of a nasopharyngeal swab. J Clin Microbiol 1994; 32: 1054-1057.

15. de Lamballerie $X$, Zandotti C, Vignoli C, Bollet C, de Micco P. A one-step microbial DNA extraction method using "Chelex 100" suitable for gene amplification. Res Microbiol 1992; 143: 785-790.

16. Makowski GS, Davis EL, Aslanzadeh J, Hopfer SM. Enhanced direct amplification of guthrie card DNA following selective elution of PCR inhibitors. Nucleic Acids Res 1995; 23: 3788-3789.

17. Crowe J, Feuser P, Goergen B. Rapid nucleic acid purification for reliable PCR. J NIH Res 1993; 5: 73. 